\title{
Examining the Effectiveness of Web-Based Learning Tools in Middle and Secondary School Science Classrooms
}

\author{
Robin Kay \\ University of Ontario Institute of Technology, \\ Oshawa, Ontario, Canada
}

\author{
robin.kay@uoit.ca
}

\begin{abstract}
The purpose of the following study was to examine the impact of web-based learning tools (WBLTs) in science classrooms (grades 7 to 10) from the perspective of both teachers and students. Survey, qualitative, and student performance data were collected from a sample of 11 teachers and 371 students. Teachers were very positive about the learning benefits, design, and engagement value of WBLTs. Students were more critical, but still positive about these same features. Qualitative data suggested that students appreciated visual scaffolding, ease of use, engagement, and using technology. Student performance based on five knowledge categories (remembering, understanding, applying, analyzing, and evaluating) increased significantly when WBLTs were used. Finally, middle and secondary school students had similar attitudes toward WBLTs, but older students showed higher learning performance gains.
\end{abstract}

Keywords: web based learning tools (WBLTs); instructional design and evaluation; learning objects; online learning tools; teaching and learning; student engagement; science

\section{Introduction}

Many students today have grown up with ubiquitous access to technology and the Internet earning them the title of the "net generation" (Montgomery, 2009; Palfrey \& Gasser, 2008; Tapscott, 2008). Outside the classroom, these students use the web to perform a wide range of personallymeaningful tasks including communicating, socializing, searching, learning, and entertaining themselves (Tapscott, 2008). Inside the classroom, technology is used sporadically and the overall impact on learning appears to be negligible (e.g., Cuban, 2001; Roberston, 2003; Russell, Bebell, O'Dwyer, \& O'Connor, 2003). Numerous barriers to using technology, including access to computers, time, and negative attitudes (Eifler, Greene, \& Carroll, 2001; Strudler \& Wetzel, 1999; Thompson, Schmidt, \& Davis, 2003; Wepner, Ziomek, \& Tao, 2003), have contributed to

Material published as part of this publication, either on-line or in print, is copyrighted by the Informing Science Institute. Permission to make digital or paper copy of part or all of these works for personal or classroom use is granted without fee provided that the copies are not made or distributed for profit or commercial advantage AND that copies 1) bear this notice in full and 2) give the full citation on the first page. It is permissible to abstract these works so long as credit is given. To copy in all other cases or to republish or to post on a server or to redistribute to lists requires specific permission and payment of a fee. Contact Publisher@InformingScience.org to request redistribution permission. the limited impact of computer-based learning tools. It is argued that webbased learning tools (WBLTs), also known as learning objects, offer a number of key features that address possible barriers and support student learning, particularly in the subject area of science. The purpose of this study was to explore the impact of WBLTs in middle and secondary school science classrooms. 


\section{Literature Review}

\section{Definition}

WBLTs are defined in this paper as "interactive web-based tools that support learning of a specific concept by enhancing, amplifying, and/or guiding the cognitive processes of learners." This definition is an amalgamation of previous efforts to define learning objects (Agostinho, Bennett, Lockyer, \& Harper, 2004; Butson, 2003; McGreal , 2004; Parrish, 2004; Wiley et al., 2004). The WBLTs used in the current study allowed students to experiment, manipulate variables, apply concepts, or answer questions based on formal presentation of material targeting a relatively narrow concept. The term "web-based learning tool" is used because it clearly communicates many features of the proposed operational definition, namely tools that students and teachers access from the web to support learning, whereas the term "learning object" is more general.

\section{Teaching and learning benefits of using WBLTs}

WBLTs offer several promising solutions to the challenges that everyday teachers face with respect to using technology. First and foremost, WBLTs are easy to use. Teachers, even those who have limited computer-based skills, do not need to devote considerable blocks of time toward understanding how to use these straightforward tools (Gadanidis, Gadanidis, \& Schindler, 2003; Kay \& Knaack, 2007). Second, good WBLTs have well defined objectives and a clear, narrow focus making it easier to develop effective lesson plans and integration strategies (Kay \& Knaack, 2007). Third, WBLTs are readily accessible over the Internet. Given that over $90 \%$ of all public schools in North America and Europe now have access to the Internet (and therefore WBLTs) with most having high-speed broadband connections, teachers need not worry about software accessibility (e.g., Compton \& Harwood, 2003; Organization for Economic Co-operation and Development [OECD], 2006). Finally, reusability permits WBLTs to be useful for a large audience, particularly when the objects are placed in well organized, searchable databases (e.g., Agostinho et al., 2004; Duval, Hodgins, Rehak \& Mason, 2003).

Regarding learning, one particularly noteworthy feature of WBLTs is the use of visual supports to help make abstract concepts more easily understood (Kay \& Knaack, 2008a, 2008c; Sedig \& Liang, 2006), often by reducing working memory and cognitive load (Sedig \& Liang, 2006). Another important learning feature of WBLTs is the inclusion of clear learning goals and immediate feedback, characteristics that often lead to increased motivation (Barkley, 2010; Wlodkowski, 2008). Finally, WBLTs permit students to control the pace of learning thereby providing easier digestion of new concepts (Bransford, Brown, \& Cocking, 2000; Kay, 2008a, 2008c; Willingham, 2009).

\section{WBLTs in middle and secondary school classrooms}

Research on the use of WBLTs in science is relatively new and limited. Only eight peer-review articles could be located on the use of WBLTs in middle (Akpinar \& Bal, 2006; Liu \& Bera, 2005; Nurmi \& Jaakkola, 2006) and secondary school science classrooms (Kay \& Knaack, 2007, 2008a, 2008b, 2009a; Lowe, Schibeci, Cummings, Phillips, \& Lake, 2010), all of which have been published within the last five years. Key findings have targeted five areas: attitudes toward learning and WBLTs, attitudes toward WBLT design, attitudes toward the engagement of WBLT, student performance, and grade level differences.

\section{Attitudes toward learning}

With respect to attitudes toward learning, seven studies suggested that students believe learning objects are helpful. Visual supports (Kay \& Knaack, 2007, 2008a, 2008b, 2009a; Lowe et al., 2010), being able to control the pace of learning (Nurmi \& Jaakkola, 2006), and timely feedback 
(Nurmi \& Jaakkola, 2006) were viewed as clear advantages to using WBLTs. Kay \& Knaack (2007, 2008a, 2008b, 2009a) reported that teachers and, to a lesser extent, students were positive about the impact of WBLTs on learning. Finally, Akinpar \& Bal (2006) noted that students like the immediate feedback provided by a WBLT and the ability to replay and redo tasks for mastery.

\section{Attitudes toward design}

The main finding noted by researchers regarding design is that students find WBLTs easy to learn and use (Kay \& Knaack, 2007, 2008a, 2008b, 2009a; Lowe et al., 2010; Nurmi \& Jaakkola, 2006). Students also respond well to the graphics and animations provided in WBLTs (Kay \& Knaack, 2007, 2008a, 2008b, 2009a). Problem areas noted are excessive text (Kay \& Knaack, 2007, 2008a, 2008b, 2009a; Lowe et al., 2010), poor quality help features, and limited control over learning (Kay \& Knaack, 2007, 2009a). Only one study looked at teacher attitudes toward WBLT design in detail (Kay \& Knaack, 2009a). It was noted that teachers found WBLTs easy to use and, overall, rated the design of WBLTs higher than students.

\section{Attitude toward engagement}

Perceptions of the engagement and WBLTs vary. Kay \& Knaack (2007, 2008a, 2008b, 2009a) reported that students were somewhat engaged when using WBLTs. Students particularly liked the interactive features and using technology in general. Two other studies (Nurmi \& Jaakkola, 2006; Lowe et al., 2010) remarked that students thought that using WBLTs was fun and enjoyable. Teachers seem to be very positive about the engagement value of WBLTs - more positive than students (Akinpar \& Bal, 2006; Kay \& Knaack, 2007, 2008a, 2008b, 2009a).

\section{Learning performance}

Six studies examining the impact of WBLTs on student performance reported significant gains, sometimes as high as 40\% (Akinpar \& Bal, 2006; Kay \& Knaack, 2008a, 2008b, 2009a; Liu \& Bera, 2005; Nurmi \& Jaakkola, 2006). However, it is not clear from these studies what type of knowledge was gained. In other words, it was not known whether students were acquiring basic or higher level skills as a result of using WBLTs.

\section{Grade level}

Limited research has been conducted on the impact of grade level and the use of WBLTs. Kay \& Knaack $(2007,2008 \mathrm{a})$ reported that older students (Grade 12) were more positive about WBLTs and performed better than younger students (grade 9 and 10). No research, though, has been conducted comparing middle and secondary schools students. Since WBLTs were originally designed for older students (Haughley \& Muirhead, 2005), it is conceivable that they may not work as well for younger students, who may be less prepared to engage self-guided discovery learning. More research is needed to assess the influence of grade level on using WBLTs, particularly the middle and secondary school level.

\section{Purpose}

The purpose of this study was to examine the influence of WBLTs on teacher attitudes, student attitudes, and student performance in middle and secondary school science classrooms.

\section{Method}

\section{Overview}

The following protocol was followed to maximize the integrity of data collected: 
1. a relatively large, group of students was sampled;

2. reliable, valid, and research-based survey tools were employed to collect data on student and teacher attitudes toward WBLTs;

3. the credibility (inter-rater agreement), transparency (coding scheme presented), and objectivity (citing negative cases) of qualitative data were addressed;

4. good quality science-based WBLTs were pre-selected for teachers based on the Kay \& Knaack's (2008c) multi-component approach for evaluating WBLTs;

5. pre-designed lesson plans were created by trained teachers and derived from previous research looking at effective strategies for using WBLTs (Kay, Knaack, \& Muirhead, 2009); and

6. an enhanced measure of student performance was developed for each WBLT based on the revised Bloom taxonomy (Anderson \& Krathwhol, 2001).

\section{Sample}

\section{Student}

The student sample consisted of 371 middle and secondary school students (166 males, 196 females, 1 missing data) who were 13 to 16 years of age $(\mathrm{M}=14.8, \mathrm{SD}=0.71)$. A majority of students reported average grades of 60 to 69 percent $(n=72,19 \%), 70$ to 79 percent $(n=122,33 \%)$, or 80 to 89 percent $(n=101 ; 27 \%)$. Over three quarters of the students $(n=288)$ agreed or strongly agreed that they were good at working with computers. The sample population was gleaned from 17 different middle and secondary school classrooms located within two suburban regions, each with over 500,000 people.

\section{Teachers}

Five middle school and six secondary school teachers participated in the current study ( 2 males, 9 females). Specific grades taught were seven $(n=2)$, eight $(n=3)$, nine $(n=5)$ and $10(n=1)$. Teaching experience ranged from 0.5 to 22 years with a mean of $5.7(\mathrm{SD}=6.1)$. Ten out of eleven teachers agreed that they were comfortable with and liked using computers at school. Frequency of typical classroom computer use was highly variable with two teachers never using computers, two teachers using computers each term, five teachers using computers monthly, one teacher using computers weekly, and one teacher using computers on a daily basis.

\section{WBLT and lesson plans}

Four teachers, who were not involved in the study, were trained in a two-day, hands on workshop focusing on (a) how to select WBLTs for the classroom and (b) developing effective lesson plans. The criteria for selecting WBLTs were based on Kay \& Knaack's (2008c) multi-component model for assessing WBLTs. The lesson plan design was derived from the results of Kay, Knaack, \& Muirhead's (2009) study on effective strategies for using WBLTs. Essential components of a standard lesson plan included (a) a guiding set of questions, (b) a structured wellorganized plan for using the WBLTs, and (c) time to consolidate concepts learned. Lessons were 70 minutes in duration and comprised of an introduction (10 $\mathrm{min}$.), guiding questions and activities involving the use of the WBLT (50 minutes), and consolidation (10 min).

Over a period of 2 months, a database of 44 lesson plans and WBLTs was created. Twelve unique WBLTs were selected by teachers from the WBLT database. These WBLTs were used by 17 different classes - seven of the WBLT lessons were teacher-led and 10 were student-led. See Appendix A (Kay, 2011a) for links to all WBLTs used and a detailed description of each lesson plan, including pre- and post-tests. 


\section{Procedure}

Science teachers from two boards of education were informed of the research study. Teachers who volunteered to participate received one full day of training on using WBLTs and implementing the pre-designed lesson plans. After the training session, if teachers still wanted to be part of the study, they were then asked to use at least one WBLT in their science classroom. All teachers in the workshop chose to participate in the study. Seven teachers used only one WBLT, three teachers used two WBLTs, and one teacher used four WBLTs. The maximum number of WBLTs used by a student was two, but most students used only one.

Email support was available for the duration of the study. Each student in a given teacher's class participated in the WBLT lesson, but survey data and learning performance scores were only collected from students with signed parental permission forms.

\section{Data Sources}

\section{WBLT evaluation scale for teachers}

After the WBLT lesson was completed, each instructor was asked to fill in the WBLT Evaluation Scale for Teachers. This scale consisted of 11, seven-point Likert scale items examining attitudes about how much students learned (learning construct - 4 items), the design of the WBLT (design construct - 3 items) and the degree to which students were engaged when using the WBLT (engagement construct -4 items). The three constructs selected were derived from an extensive review of research on the evaluation of learning objects (see Kay \& Knaack, 2007, 2009a). The scale demonstrated fair to moderate reliability and good construct validity (Kay, Knaack, \& Petrarca, 2009). Internal scale reliability estimates for the current study were 0.94 (perceived learning), 0.85 (design of WBLT), and 0.85 (engagement). See Appendix B (Kay, 2011b) for a copy of the WBLT Evaluation Scale for Teachers.

\section{Teacher comments}

Teachers were asked three open ended questions about (a) the overall impact that the WBLT had on learning, (b) technical challenges experienced, and (c) advice for future science teachers who might want to use WBLTs in their classrooms.

\section{WBLT evaluation scale for students}

After the WBLT lesson was finished, students with signed permission forms were asked fill in the WBLT Evaluation Scale for Students which consisted of 13, seven-point Likert scale items asking students about their attitudes about how much they had learned (learning construct - 5 items), the design of the WBLT (design construct - 4 items) and how much they were engaged while using the WBLT (engagement construct - 4 items). The constructs selected were anchored in a thorough review of the literature on evaluating learning objects (Kay \& Knaack, 2007, 2009b). The scale showed good reliability, face validity, construct validity, convergent validity, and predictive validity (Kay \& Knaack, 2009b). Internal-reliability scale estimates in the current study were 0.94 (perceived learning), 0.87 (design of WBLT), and 0.93 (engagement). See Appendix C (Kay, 2011c) for a copy of the scale used.

\section{Student comments}

Students were asked open-ended questions about what they liked and disliked about the WBLT they used. Comments were organized into the three general categories observed in previous research on WBLTs: learning, design, and engagement. Sub-categories within these three areas emerged from reading all student responses. The specific criteria for each sub-category are pro- 
vided in Appendix D (Kay, 2011d). After a comment was assigned to a category, it was rated on a five-point Likert scale $(-2=$ very negative, $-1=$ negative, $0=$ neutral, $1=$ positive, $2=$ very positive). Two raters independently assessed all student comments and initially achieved interrater reliability of $52 \%$ on the categories and $57 \%$ on the ratings. The two raters then discussed differences in coding and re-rated the comments independently. The final inter-rater reliability estimates were $97 \%$ for categories and $98 \%$ for numerical ratings.

To assess impact of any single comment category both mean score and frequency of comments were taken into account. Using mean score exclusively might under or overestimate the impact of a category with a limited number of comments. Reporting frequency of comments only, disregards the intensity of student comments. Therefore, the total impact of a student comment category was calculated by multiplying the mean rating by the total number of students who made a comment. For example, in Table 3, the total impact of visual supports on learning was calculated by multiplying the mean which was 1.10 by the number of students who commented about visual supports (58) for a total of 64.0.

\section{Student performance}

Students completed a pre- and post-test based on the content of the specific WBLT they used in class. Although formal statistical validity was not established, these tests were carefully designed to match the learning goals of the WBLT by four experienced middle and high school teachers. In addition, an associate professor at the faculty of education reviewed all tests for content validity.

All tests consisted of two to six questions worth a total of five to eight marks. The type of questions varied according to the learning goals of the WBLT and included open-ended, short-answer, multiple choice, fill in the blank, and application problems. All pre- and post-tests with scoring rubrics are provided in Appendix A within the lesson plans (Kay, 2011a). Note that pre- and post- tests were identical in content and format. All questions from the pre- and post-test were assigned a category (remembering, understanding, application, analysis, or evaluation) based on the revised Bloom's Taxonomy (Anderson \& Krathwhol, 2001). The percent difference between pre- and post-test scores was used to assess changes in student performance on five possible Blooms' taxonomy knowledge categories: remembering, understanding, application, analysis, and evaluation. The proportion of knowledge categories assessed varied according to the type and learning goals of the specific WBLT used.

\section{Research Questions}

The following research questions guided the data analysis for assessing the use of WBLTs in middle and secondary school science classrooms.

1. What are teacher attitudes toward the use of WBLTs? (from teacher survey and open ended questions);

2. What are student attitudes toward the use of WBLTs? (from student survey and open ended questions);

3. How do WBLTs affect student performance? (from student pre- and post-test scores); and

4. Are there differences between middle and secondary school students with respect to attitudes toward WBLTs and learning performance? (from student survey and pre-post test scores). 


\section{Results}

\section{Lesson Plan Evaluation}

The lesson plans for the WBLTs were designed by other teachers, so it is important to evaluate the extent to which teachers in this study accepted these lesson plans. All teachers agreed or strongly agreed that the lesson plans were easy to follow. Over $95 \%$ of the teachers believed that the lesson plans matched their teaching style. Eighty-two percent of the teachers felt the handouts were clear and over $90 \%$ believed they were useful. All teachers felt the lesson plans were well designed and $71 \%$ believed there was no need to make changes.

\section{Teacher Attitudes toward WBLTs}

\section{Survey data - Learning construct}

The mean rating for impact on learning (items 8a to 8d - Appendix B in Kay, 2011b) was 25.1 $(\mathrm{SD}=2.9)$ or an average of 6.3 on a 7-point scale. This indicates that most teachers agreed or strongly agreed that the WBLT they used had a positive effect on student learning (Table 1).

\section{Survey data - Design construct}

The mean rating of WBLT design (Items 7a to 7c - Appendix B in Kay, 2011b) was 18.5 (SD = $1.5)$ or an average of 6.2 on a 7-point scale. Most teachers agreed or strongly agreed the WBLTs used in this study were well designed (Table 1).

\section{Survey data - Engagement construct}

Teachers also rated engagement of WBLTs (Items 9a to 9d- Appendix B in Kay, 2011b) high with a mean score of $25.6(\mathrm{SD}=2.4)$ or an average of 6.4 on a 7 -point scale (Table 1$)$. This means that most teachers agreed or strongly agreed that the WBLTs engaged students.

Table 1: Teacher Ratings of Learning, Design, and Engagement for WBLTs $(n=17)$

\begin{tabular}{lrccc}
\hline Scale & $\begin{array}{l}\text { No. } \\
\text { Items }\end{array}$ & $\begin{array}{c}\text { Possible } \\
\text { Range }\end{array}$ & $\begin{array}{c}\text { Actual Range } \\
\text { Observed }\end{array}$ & Mean (S.D) \\
\hline Learn & 4 & 4 to 28 & 17 to 28 & $25.1(2.9)$ \\
Design & 3 & 3 to 21 & 15 to 21 & $18.5(1.5)$ \\
Engagement & 4 & 4 to 28 & 20 to 28 & $25.6(2.4)$ \\
\hline
\end{tabular}

\section{Teacher comments - Overall impact}

Nine out of 11 teachers in this study commented that the main impact of using WBLTs was on learning. Sample comments were:

"This [WBLT] allowed students to interact with the visualization software to test their previous knowledge, and then further cement their understanding of the general shape and function of different cell organelles."

"The concept was learned more quickly and definitely better understood than in previous years when I didn't use the [WBLT]." 
A secondary theme regarding the use of WBLTs was engagement which was noted by four teachers (e.g., "The students really enjoyed using the learning object and the computers").

\section{Teacher comments - Technology problems}

Seven of the 11 teachers reported no technology problems when using WBLTs. Minor issues that did emerge included students having trouble typing in a long web address for a particular WBLT $(n=1)$, some computers freezing $(n=1)$, and having difficulty with Internet connections $(n=2)$.

Overall, there appeared to be no substantial technological challenges that prevented students from using WBLTs.

\section{Teacher comments - Advice for future teachers}

Four themes emerged with respect to advice to future teachers planning to use WBLTs. The first theme was to "use them" - some teachers were very enthusiastic about using WBLTs. The second theme was "preparation" - several teachers commented that it was necessary to go over how to use WBLTs effectively with the students before letting them work on their own. The third theme was "time" - a few teachers noted that it took more time to use WBLTs than they anticipated. The final theme was that WBLTs can work well as demonstration tools - they did not necessarily have to be used by students on independent computers.

\section{Student Attitudes toward WBLTs}

\section{Survey data - Learning construct}

Students rated WBLTs lower than teachers with respect to learning (Items 8a to 8f- Appendix C in Kay, 2011c) $(\mathrm{M}=32.21, \mathrm{SD}=6.2)$ with a mean item rating of 5.4 out of 7 . This means that students, on average, slightly agreed or agreed that WBLTs helped them learn. The broad range of scores (6 to 42) indicates that there was considerable variability among student attitudes toward the learning value of WBLTs (Table 2).

\section{Survey data - Design construct}

Students rated the design of WBLTs (Items 7a to 7d - Appendix C in Kay, 2011c) slightly higher than the learning value $(\mathrm{M}=22.5, \mathrm{SD}=4.0)$, although the mean rating (5.6 out of 7$)$ was still lower than that of the teachers. The range of student attitudes toward WBLT design (4 to 28) revealed considerable variability (Table 2 ).

\section{Survey data - Engagement construct}

Student ratings of WBLT engagement (Items 9a to 9d - Appendix C in Kay, 2011c) were moderate $(\mathrm{M}=20.7, \mathrm{SD}=5.0)$ with a mean item rating of 5.2 out of 7 . This means that students, on average, slightly agreed that the WBLT they used was engaging. High variability among student engagement ratings is supported by the wide range of scores reported (4 to 28).

Table 2. Student Rating of Learning, Design, and Engagement for WBLTs $(n=371)$

\begin{tabular}{lcccc}
\hline Scale & $\begin{array}{l}\text { No. } \\
\text { Items }\end{array}$ & $\begin{array}{c}\text { Possible } \\
\text { Range }\end{array}$ & $\begin{array}{c}\text { Actual Range } \\
\text { Observed }\end{array}$ & Mean (S.D) \\
\hline Learn & 6 & 6 to 42 & 6 to 42 & $32.2(6.2)$ \\
Design & 4 & 4 to 28 & 4 to 28 & $22.5(4.0)$ \\
Engagement & 4 & 4 to 28 & 4 to 28 & $20.7(5.0)$ \\
\hline
\end{tabular}




\section{Student comments about WBLTs}

Over 570 student comments were collected from 288 students. The average number of comments per student was $2.0(\mathrm{SD}=1.3)$ with a range of 1 to 8 . A summary of the comments based on the assigned categories is presented in Table 3 . Sample comments for each category of student comments are displayed in Appendix E (see Kay, 2011e). Positive perceptions about WBLTs, in general, outnumbered negative perceptions by a factor of 3 to 1 . Typical responses were as follows:

"I liked everything." [positive]

“There wasn't anything I didn't like." [positive]

"Overall, I did not like the program at all." [negative]

With respect to learning, visual supports and overall learning benefits were rated the highest.

Sample comments included:

"I really liked the diagrams- it helped me a lot to understand." [visual support]

"I liked how there were diagrams that moved and helped you understand the stages better." [visual support]

"It made it easier to understand and helped me learn." [overall learning]

"It helps you learn and teaches you at the same time." [overall learning]

Learning sub-categories rated the lowest included pace of learning and pedagogical challenge.

Some students thought the pace of learning was too fast (e.g., "We had to rush through it."). Others thought that the WBLTs were too confusing or overwhelming (e.g., "There was too much information to take in at once... it was hard to remember it all.").

Table 3. Summary of Student Comments about WBLTs ( $n=288$ students, 571 comments)

\begin{tabular}{|c|c|c|c|c|c|}
\hline Category & Mean (SD) & $\begin{array}{c}\text { Total } \\
\text { Comments }\end{array}$ & $\begin{array}{l}\text { Total Neg. } \\
\text { Comments }\end{array}$ & $\begin{array}{l}\text { Total Pos. } \\
\text { Comments }\end{array}$ & $\begin{array}{c}\text { Total Effect } \\
\text { Mean *n }\end{array}$ \\
\hline
\end{tabular}

\section{General}

$\begin{array}{llllll}\text { General/Overview } & 0.48(1.37) & 54 & 13 & 36 & 26.0\end{array}$

Learning

$\begin{array}{lrrrrr}\text { Visual Supports } & 1.10(0.55) & 58 & 2 & 56 & 64.0 \\ \text { Overall Learning } & 0.47(1.10) & 60 & 17 & 43 & 28.0 \\ \text { Pace } & -0.78(1.09) & 9 & 7 & 2 & -7.0 \\ \text { Challenge } & -0.88(1.01) & 43 & 36 & 7 & -38.0 \\ \text { Design } & & & & & \\ \text { Easy to Use } & 0.95(0.51) & 39 & 2 & 37 & 37.0 \\ \text { Graphics } & 0.52(1.07) & 46 & 10 & 36 & 24.0 \\ \text { Animation } & 0.56(1.08) & 27 & 7 & 20 & 15.0 \\ \text { Interactive } & 0.28(1.03) & 29 & 10 & 19 & 8.0 \\ \text { Theme } & -0.13(1.36) & 16 & 9 & 7 & -2.0 \\ \text { Organization } & -0.08(1.25) & 24 & 14 & 10 & -2.0 \\ \text { Control } & -0.20(1.10) & 5 & 3 & 2 & -1.0 \\ \text { Audio } & -1.00 & 1 & 1 & - & -1.0\end{array}$




\begin{tabular}{lrrrrr} 
Text & $-1.14(0.38)$ & 7 & 7 & - & -8.0 \\
Help & $-1.06(0.66)$ & 17 & 16 & 1 & -18.0 \\
Engagement & & & & & \\
Engaging & $0.54(1.21)$ & 57 & 17 & 40 & 37.0 \\
Compare & $0.89(0.58)$ & 27 & 1 & 26 & 24.0 \\
Technology & $0.54(0.94)$ & 39 & 8 & 31 & 21.0 \\
\hline
\end{tabular}

Regarding student ratings of design, ease of use was the highest rated feature (e.g. "It was very straightforward."), followed by appreciation for graphics (e.g., "I like the graphics. They were well done and clear.") and animations (e.g., "I liked the short videos."). Text (e.g., "The learning tool had a higher vocabulary for certain phrases, was very wordy.") and help features (e.g., "[You need] better instructions on what to do.") were rated the lowest.

Finally, for ratings of WBLT engagement, a number of students were positive about the motivational aspects of WBLTs (e.g., "[Using WBLTs] made learning science more fun."). Some students thought using WBLTs was superior to other teacher methods (e.g., "It is more interesting then copying down notes.") and other students enjoyed using technology, in general (e.g., "I liked the fact that it was on the computer.").

\section{Learning performance}

Six paired t-tests were performed to assess differences between pre- and post-test scores on the five knowledge categories of questions assessed and total test score. Typically a MANOVA is a preferred statistical procedure to employ when there are multiple dependent variables. However, each WBLT had unique learning goals that did not target all five Bloom's knowledge categories. Some WBLTs focused on basic understanding, while others focused on application and analysis. Consequently, group comparison using a MANOVA eliminated considerable data. Therefore multiple t-tests were used to analyze the maximum amount of information possible. All question categories showed significant gains (see Table 4). Scores increased 21 to 57\% with large effect sizes according to Cohen $(1988,1992)$.

Table 4. Pre-Post Test Score Differences

\begin{tabular}{lllcccc}
\hline Question Type & $\begin{array}{l}\text { Pre-Test } \\
\text { Mean (\%) }\end{array}$ & $\begin{array}{l}\text { Post Test } \\
\text { Mean (\%) }\end{array}$ & $\begin{array}{c}\% \\
\text { Change }\end{array}$ & n & t & $\begin{array}{c}\text { Effect } \\
\text { Size }\end{array}$ \\
\hline Remembering & $35.1(34.1)$ & $69.8(35.4)$ & $34.7 \%$ & 297 & $-13.7 *$ & 1.00 \\
Understanding & $20.5(31.8)$ & $66.7(40.3)$ & $46.1 \%$ & 184 & $-13.8 *$ & 1.27 \\
Application & $34.8(33.8)$ & $56.2(28.9)$ & $21.5 \%$ & 105 & $-8.4 *$ & 0.68 \\
Analysis & $5.6(21.9)$ & $62.2(45.4)$ & $56.7 \%$ & 45 & -8.3 & 1.59 \\
Evaluation & $60.4(39.0)$ & $83.3(31.8)$ & $22.9 \%$ & 24 & $-2.7 * *$ & 0.64 \\
Total Score & $32.9(25.9)$ & $68.5(24.6)$ & $28.3 \%$ & 314 & $-22.3 *$ & 1.41 \\
& & & & & & \\
\hline
\end{tabular}

* $\quad p<.001$

$* * \quad p<.05$ 


\section{Middle vs. secondary school students - Attitude and performance}

To assess whether grade level had an impact on student attitudes toward WBLTs, a MANOVA was run comparing middle vs. secondary schools students and the three attitude constructs: learning, design, and engagement. Computer comfort level, subject area comfort level, and average grade in subject area were entered as covariates to ensure that any differences observed were due to grade level. No significant differences were observed between middle and secondary school students and their attitudes toward learning, design, and engagement (Table 5).

Percent change in learning performance for secondary school students was significantly higher than middle school students for remembering $(p<.005)$, understanding $(p<.005)$, and application $(p<.005)$ knowledge categories. The effect size for these differences based on Cohen's d are considered moderate (Cohen, 1988,1992) (Table 5). The analysis and evaluation knowledge categories were not compared because of insufficient sample size.

Table 5. Student Attitudes about WBLTs and Learning Performance as a Function of Grade Level

\begin{tabular}{lcccccc}
\hline & \multicolumn{2}{c}{ Middle School } & \multicolumn{2}{c}{ Secondary School } & Test & $\begin{array}{c}\text { Effect Size } \\
\text { Cohen's D }\end{array}$ \\
\hline & $M$ & $(S D)$ & $M$ & $(S D)$ & & \\
$\begin{array}{l}\text { Perceptions of } \\
\text { Learning }\end{array}$ & 22.6 & $(4.7)$ & 22.5 & $(3.7)$ & $F=0.7$ & --- \\
Design & 32.2 & $(7.1)$ & 32.3 & $(6.0)$ & $F=2.2$ & --- \\
Engagement & 20.5 & $(6.3)$ & 20.9 & $(4.5)$ & $F=3.8$ & --- \\
\hline
\end{tabular}

Learning Performance

( $\%$ Change)

$\begin{array}{lrrrrr}\text { Remembering } & 20.0 & (50.1) & 39.0(40.9) & t=3.2 * & 0.41 \\ \text { Understanding } & 32.4 & (53.7) & 54.1(38.1) & t=3.2 * & 0.47 \\ \text { Application } & 8.0 & (27.7) & 25.7(24.5) & t=3.1 * & 0.68\end{array}$

* $\quad p<.005$

\section{Discussion}

The purpose of this study was to examine the influence of WBLTs on teacher attitudes, student attitudes, and learning performance. Each of these will be discussed in turn.

\section{Teacher Attitudes toward the Use of WBLTs}

The survey data strongly suggested that middle and secondary school science teachers thought that the WBLTs they used were well designed, engaging tools that supported learning. Openended comments from teachers were consistent with the survey data. Teachers believed that the use of WBLTs increased student learning and engagement. These results are in line with those reported previously on teacher perceptions of WBLT design (Kay \& Knaack, 2009a), engagement, and learning (Akinpar \& Bal, 2006; Kay \& Knaack, 2007, 2009a).

It is worth noting that over $60 \%$ of the teachers in this study had no technology problems whatsoever while using WBLTs. The remaining group reported minor software and hardware problems that did not appear to have a significant impact on the lesson being taught. These findings, coupled with the fact that most teachers thought WBLTs were easy to learn, are consistent with pre- 
vious research (Kay \& Knaack, 2007, 2009a; Lowe et al., 2010; Nurmi \& Jaakkola, 2006) and suggest that computer skills and time are not significant barriers to using WBLTs. Teachers can concentrate on the core science concepts being taught instead of distracting and sometimes serious technological issues.

Several recent studies have claimed there is a need for thoughtful teaching strategies to be used in conjunction with WBLTs (Kay \& Knaack, 2009a; Lowe et al., 2010). Teachers in this study gave high ratings to the pre-designed lesson plans and support materials noting that they were easy to use, well-designed, and matched their personal teaching style. Pre-designed, research-based lesson materials have the potential to overcome a third barrier to using computers in the classroom, namely, not understanding how to integrate technology effectively into a lesson.

\section{Student Attitudes toward the Use of WBLTs}

Middle and secondary students agreed that science-based WBLTs help them learn, a result also reported in previous research (Kay \& Knaack, 2007, 2009a; Lowe et al., 2010). However, the wide range of learning, design, and engagement survey ratings, suggests that some students struggle when using WBLTs. For example, a small group disliked using WBLTs, commenting that the pace of the WBLT lesson was too fast or the content of the WBLT was overwhelming. Finding the optimum pace and cognitive challenge for all students in a science class may be difficult, regardless of teaching method or tool used. Teachers may need to provide additional scaffolding for students who are struggling while using WBLTs.

Design was the highest rated feature of WBLTs, possibly a reflection of the effort and time spent by trained teachers to search for effective science-based WBLTs. Students rated ease of use and visual features (graphics and animations) the highest. A small group struggled with the quality and amount of text presented in some WBLTs, as well as the effectiveness of help features. These findings are similar to those observed in previous studies (Kay \& Knaack, 2007, 2009a; Lowe et al., 2010; Nurmi \& Jaakkola, 2006). When selecting a WBLT, ease of use, quality of graphics, limited text, and effective help are useful discriminating features to look for.

Students were moderately engaged while using WBLTs, a result that was reported by Kay \& Knaack $(2007,2009 a)$. On the other hand, anecdotal results of Nurmi \& Jaakkola (2006) and Lowe et al. (2010) conveyed a much higher level of engagement. The current study used reliable, valid data collection tools similar to those of Kay \& Knaack (2007, 2009a), so the data may more accurately reflect student feelings of engagement. A number of students commented that they (a) thought WBLTs were interesting or fun, (b) liked using technology, and (c) felt WBLTs were more effective than other teaching methods. This enthusiasm appears to reflect a genuine desire to use more technology and is not surprising given the wide-spread use of computers and the Internet by today's "net generation" (Montgomery, 2009; Palfrey \& Gasser, 2008; Tapscott, 2008).

\section{Student Learning Performance}

Significant increases in student performance were observed when science-based WBLTs were used. Gains of 21 to $57 \%$ and effect sizes in the large range (Cohen, 1988, 1992) suggest that increases observed were meaningful, not just statistically significant. These increases are consistent with Kay \& Knaack's (2009a) findings, although the magnitude of change appears to be higher in the current study, possibly because of the quality of WBLTs selected and lessons plans created.

No previous research has examined the specific types of knowledge gained when WBLTs were used. Five categories of knowledge (remembering, understanding, application, analysis, and evaluation) were assessed in the current study based on the revised Bloom's Taxonomy (Ander- 
son \& Krathwhol, 2001). Significant gains were observed in all five categories, with the largest increases in analysis and understanding-based questions (46\%) and the smallest increases in application $(21 \%)$ and evaluation problems $(23 \%)$. This preliminary evidence should be treated with caution, though, particularly because the sample size for each knowledge category varied considerably. Ninety-five percent of the students responded to questions involving remembering, but only eight to 14 percent of the students answered questions involving analysis and evaluation respectively.

\section{Middle vs. Secondary School Students}

No significant differences were observed between middle and secondary students' attitudes toward WBLTs. This result is inconsistent with previous research on grade level differences in secondary school and the use of WBLTs (Kay \& Knaack, 2007, 2008a). It is conceivable that the sample population in the current study, consisting primarily of grade seven, eight, and nine students, was more homogeneous than samples studied in previous research which spanned grades nine to twelve. Since all of the students in this study are members of the "net generation" described by Tapscott (2008), regardless of grade level, it is speculated that WBLTs may be viewed as just another interactive interface in a long list of Internet tools used on a daily basis.

Older students in grades nine and 10 performed significantly better than younger students in grade seven and eight in remembering, understanding, and application knowledge areas. This result was partially supported by research suggesting that older students may be more serious about using computers for learning rather than entertainment (e.g., Colley, 2003; Colley \& Comber, 2003; Kay \& Knaack $(2007,2008$ a) reported a modest, positive age effect on general learning performance in a secondary school environment; however, the results in the current study are more robust, perhaps because the age range extended down to middle school.

One possible explanation for the impact of grade level on learning performance might involve the range of cognitive skills required to use a WBLT including reading instructions, writing down results, interpreting and digesting "what-if" scenarios, and working independently. Younger students may be more overwhelmed by the cognitive effort required to learn with WBLTs.

\section{Implications for Education}

The results of any one study should be treated cautiously with respect to providing educational recommendations. Nonetheless, several implications, however tentative, emerge for middle and secondary school teachers planning to use science-based WBLTs.

First, while there are always exceptions, both teachers and students can expect that most WBLTs will be easy to use with minimal technological problems. Second, when searching for a sciencebased WBLT, aside from using Kay \& Knaack's (2008c) multi-component model, teachers should look for good visual scaffolding that provides context and concrete support for learning the specific science-based concepts being taught. In addition, WBLTs with clear, concise instructions and minimal text will probably incur the least amount of resistance from students. Third, using carefully selected and meaningful lesson plans anchored in Kay, Knaack, and Muirhead's (2009) teaching model is a reasonable prescription for positive teacher and student attitudes as well as significant performance gains. Fourth, WBLTs have the potential to improve student learning of basic and higher level concepts. Fifth, if WBLTs are used with middle school students, it may be prudent to offer more scaffolding and guidance to ensure gains in learning performance. Finally, teachers need to be aware the possible pitfalls of going too fast and excessive cognitive challenge. Even though WBLTs are easy to use, the science concepts addressed may be difficult particularly when the pace of learning is too quick or there is too much text to read. 


\section{Caveats and Future Research}

While an attempt was made to examine different types of knowledge gains based on the revised Blooms taxonomy, more research is needed to firmly establish whether WBLTs can reliably improve the broad range of knowledge areas suggested by Anderson \& Krathwhol (2001). Furthermore, more research is needed to determine which specific features of WBLTs uniquely promote remembering, understanding, application, analysis, and evaluation of science concepts. Second, while the student sample was large, the number of teachers was small; therefore, more research is needed on teacher perceptions. Third, the results of the current study reflect one-time use of WBLTs. It is not known whether teachers and students would enjoy using these tools on a regular basis. Fourth, student increases in performance, while substantial, reflect relatively short term gains. It is not clear whether the use of WBLTs is effective for establishing long-term habits of remembering, understanding, applying, analyzing, and evaluating science-based concepts. Finally, while a mixed methods approach was used, interviews and focus groups could augment the quality and interpretation of data. For example, it would be helpful to understand the variability in student attitudes toward WBLTs in more depth.

\section{References}

Agostinho, S., Bennett, S., Lockyear, L., \& Harper, B. (2004). Developing a learning object metadata application profile based on LOM suitable for the Australian higher education market. Australasian Journal of Educational Technology, 20(2), 191-208. Retrieved from http://www.ascilite.org.au/ajet/ajet20/agostinho.html

Akinpar, Y., \& Bal, V. (2006). Student tools supported by collaboratively authorized tasks: The case of work learning unit. Journal of Interactive Learning Research, 17(2), 101-119.

Anderson, L. W. \& Krathwohl, D. R. (Eds.). (2001). A taxonomy for learning, teaching, and assessing: A revision of Bloom's taxonomy of educational objectives. New York: Longman.

Barkley, E. F. (2010). Student engagement techniques. San Francisco: John Wiley \& Sons.

Bransford, J. D., Brown, A. L., \& Cocking, R. R. (Eds.). (2000). How people learn. Washington, DC: National Academy Press.

Butson, R. (2003). Learning objects: Weapons of mass instruction. British Journal of Educational Technology, 34(5), 667-669. doi: 10.1046/j.0007-1013.2003.00359.x

Cohen, J. (1988). Statistical power analysis for the behavioural sciences (2nd ed.). New York: Academic Press.

Cohen, J. (1992). A power primer. Psychological Bulletin, 112(1), 155-159. doi: 10.1037/00332909.112.1.155

Colley, A. (2003). Gender differences in adolescents' perceptions of the best and worst aspects of computing at school. Computers in Human Behaviour, 19(6) 673-682. doi:10.1016/S0747-5632(03)00022-0

Colley, A., \& Comber, C. (2003). Age and gender differences in computer use and attitudes among secondary school students: What has changed? Educational Research, 45(2), 155-165. doi: $10.1080 / 0013188032000103235$

Compton, V., \& Harwood, C. (2003). Enhancing technological practice: An assessment framework for technology education in New Zealand. International Journal of Technology and Design Education, 13(1), 1-26. doi:10.1046/j.0007-1013.2003.00359.x

Cuban, L. (2001). Oversold and underused: Computers in the classroom. Cambridge, MA: Harvard University Press.

Duval, E., Hodgins, W., Rehak, D., \& Robson, R. (2004). Learning objects symposium special issue guest editorial. Journal of Educational Multimedia and Hypermedia, 13(4), 331-342. 
Eifler, K. Greene, T., \& Carroll, J. (2001). Walking the talk is tough: From a single technology course to infusion. The Educational Forum, 65(4), 366-375.

Gadanidis, G., Gadanidis, J., \& Schindler, K. (2003). Factors mediating the use of online applets in the lesson planning of pre-service mathematics teachers. Journal of Computers in Mathematics and Science Teaching, 22(4), 323-344.

Haughey, M., \& Muirhead, B. (2005). Evaluating learning objects for schools. Australasian Journal of Educational Technology, 21(4), 470-490. Retrieved from http://www.ascilite.org.au/ajet/ajet21/haughey.html

Kay, R. H. (2011a). Appendix A - List of WBLTs used in science study. Retrieved from http://faculty.uoit.ca/kay/res/lo/sci.html

Kay, R. H. (2011b). Appendix B - WBLT survey for teachers. Retrieved from http://faculty.uoit.ca/kay/res/lo/ts.pdf

Kay, R. H. (2011c). Appendix C - WBLT survey for students. Retrieved from http://faculty.uoit.ca/kay/res/lo/ss.pdf

Kay, R. H. (2011d). Appendix D - Coding scheme to assess student comments about WBLTs. Retrieved from http://faculty.uoit.ca/kay/res/lo/cs.pdf

Kay, R. H. (2011e). Appendix E - Sample student comments about WBLTs. Retrieved from http://faculty.uoit.ca/kay/res/lo/sc.pdf

Kay, R. H., \& Knaack, L. (2007). Evaluating the use of learning objects for secondary school science. Journal of Computers in Mathematics and Science Teaching, 26(4), 261-289. Retrieved from http://www.editlib.org.uproxy.library.dc-uoit.ca/p/23577

Kay, R. H., \& Knaack, L. (2008a). An examination of the impact of learning objects in secondary school. Journal of Computer Assisted Learning, 24(6), 447-461. doi: 10.1111/j.1365-2729.2008.00278.x

Kay, R. H., \& Knaack, L. (2008b). A formative analysis of individual differences in the effectiveness of learning objects in secondary school. Computers \& Education, 51(3), 1304-1320. doi: 10.1016/j.compedu.2008.01.001

Kay, R. H. \& Knaack, L. (2008c). A multi-component model for assessing learning objects: The learning object evaluation metric (LOEM). Australasian Journal of Educational Technology, 24(5), 574-591. Retrieved from http://www.ascilite.org.au/ajet/ajet24/kay.pdf

Kay, R. H. \& Knaack, L. (2009a). Analyzing the effectiveness of learning objects for secondary school science classrooms. Journal of Educational Multimedia and Hypermedia, 18(1), 113-135.

Kay, R. H., \& Knaack, L. (2009b). Assessing learning, quality and engagement in learning objects: The learning object evaluation scale for students (LOES-S). Education Technology Research and Development, 57(2), 147-168. doi: 10.1007/s11423-008-9094-5

Kay, R. H., Knaack, L., \& Muirhead, B. (2009). A formative analysis of instructional strategies for using learning objects. Journal of Interactive Learning Research, 20(3), 295-315. Retrieved from http://www.editlib.org.uproxy.library.dc-uoit.ca/p/26233

Kay, R. H., Knaack, L., \& Petrarca, D. (2009). Exploring teacher perceptions of web-based learning tools. Interdisciplinary Journal of E-Learning and Learning Objects, 5, 27-50. Retrieved from http://ijklo.org/Volume5/IJELLOv5p027-050Kay649.pdf

Liu, M. \& Bera, S. (2005). An analysis of cognitive tool use patterns in a hypermedia learning environment. Educational Technology, Research and Development, 53(1), 5-21. Retrieved from http://www.springerlink.com/content/1511560w3t653182/fulltext.pdf

Lowe, K., Lee, L., Schibeci, R., Cummings, R., Phillips, R., \& Lake, D. (2010). Learning objects and engagement of students in Australian and New Zealand schools. British Journal of Educational Technology, 41(2), 227-241. doi: 10.1111/j.1467-8535.2009.00964.x 
McGreal, R. (2004). Learning objects: A practical definition. International Journal of Instructional Technology and Distance Learning, 1(9). Retrieved from http://www.itdl.org/Journal/Sep_04/article02.htm

Montgomery, K. C. (2009). Generation digital. Cambridge, MA : MIT Press.

Nurmi, S., \& Jaakkola, T. (2006). Effectiveness of learning objects in various instructional settings. Learning, Media, and Technology, 31(3), 233-247. doi: 10.1080/17439880600893283

Organization for Economic Co-operation and Development (OECD). (2006). Education at a glance, p. 414. Retrieved from http://tinyurl.com/OECD-Kay

Palfrey, J., \& Gasser, U. (2008). Born digital. New York: Basic Books.

Parrish, P. E. (2004). The trouble with learning objects. Educational Technology Research \& Development, 52(1), 49-67. doi: 10.1007/BF02504772

Robertson, H. (2003). Toward a theory of negativity: Teacher education and information and communications technology. Journal of Teacher Education, 54(4), 280-296. doi:10.1177/0022487103255499

Russell, M., Bebell, D., O’Dwyer, L., \& O’Connor, K. (2003). Examining teacher technology use: Implications for preservice and inservice teacher preparation. Journal of Teacher Education, 54(4), 297-310. doi: $10.1177 / 0022487103255985$

Sedig, K., \& Liang, H. (2006). Interactivity of visual mathematical representations: Factors affecting learning and cognitive processes. Journal of Interactive Learning Research, 17(2), 179-212.

Strudler, N., \& Wetzel, L. (1999) Lessons from exemplary colleges of education: Factors affecting technology integration in preservice programs. Educational Technology Research and Development, 47(4), 63-81. doi: 10.1007/BF02299598

Tapscott, D. (2008). Grown up digital: How the net generation is changing your world. New York: McGraw-Hill.

Thompson, A. D., Schmidt, D. A., \& Davis, N. E. (2003). Technology collaboratives for simultaneous renewal in teacher education. Educational Technology Research and Development, 51(1), 73-89. doi: 10.1007/BF02504519

Wepner, S. B., Ziomek, N., \& Tao L. (2003). Three teacher educators' perspectives about the shifting responsibilities of infusing technology into the curriculum. Action in Teacher Education, 24(4), 53-63.

Wiley, D., Waters, S., Dawson, D., Lambert, B., Barclay, M., \& Wade, D. (2004). Overcoming the limitations of learning objects. Journal of Educational Multimedia and Hypermedia, 13(4), 507-521.

Willingham, D. T. (2009). Why don't students like school? San Francisco: Jossey-Bass.

Wlodkowski, R. J. (2008). Enhancing adult motivation to learn: A comprehensive guide for teaching all adults. San Francisco: Jossey-Bass.

\section{Biography}

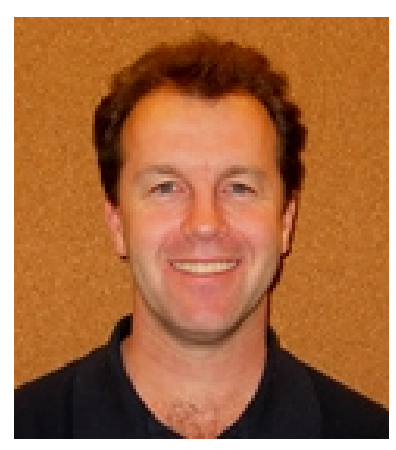

Robin Kay, Ph.D. is an Associate Professor in the Faculty of Education at the University of Ontario Institute of Technology. He has published over 50 articles and chapters in the area of computers in education, presented numerous papers at 15 international conferences, refereed five prominent computer education journals, and taught computers, mathematics, and technology for over 20 years. Current projects include research on laptop use in teacher education, classroom response systems, web-based learning tools, and factors that influence how students learn with technology. 